\title{
Comparative molecular microbial ecology of the spring haptophyte bloom in a Greenland arctic oligosaline lake
}

\author{
Susanna Theroux ${ }^{1,2}$, Yongsong Huang ${ }^{2}$ and Linda Amaral-Zettler ${ }^{1,2}$ * \\ ${ }^{1}$ Marine Biological Laboratory, Josephine Bay Paul Center for Comparative Molecular Biology and Evolution, Woods Hole, MA, USA \\ ${ }^{2}$ Department of Geological Sciences, Brown University, Providence, RI, USA
}

\author{
Edited by: \\ Angeles Aguilera, Centro de \\ Astrobiologia (INTA-CSIC), Spain \\ Reviewed by: \\ Rebecca Gast, Woods Hole \\ Oceanographic Institution, USA \\ Christine M. Foreman, Montana State \\ University, USA

\section{*Correspondence:} \\ Linda Amaral-Zettler, Department of \\ Geological Sciences, Brown \\ University, Providence, 7MBL Street, \\ Woods Hole, MA 02543, USA. \\ e-mail: amaral@mbl.edu
}

\begin{abstract}
The Arctic is highly sensitive to increasing global temperatures and is projected to experience dramatic ecological shifts in the next few decades. Oligosaline lakes are common in arctic regions where evaporation surpasses precipitation, however these extreme microbial communities are poorly characterized. Many oligosaline lakes, in contrast to freshwater ones, experience annual blooms of haptophyte algae that generate valuable alkenone biomarker records that can be used for paleoclimate reconstruction. These haptophyte algae are globally important, and globally distributed, aquatic phototrophs yet their presence in microbial molecular surveys is scarce. To target haptophytes in a molecular survey, we compared microbial community structure during two haptophyte bloom events in an arctic oligosaline lake, Lake BrayaSø in southwestern Greenland, using high-throughput pyrotag sequencing. Our comparison of two annual bloom events yielded surprisingly low taxon overlap, only $13 \%$ for bacterial and $26 \%$ for eukaryotic communities, which indicates significant annual variation in the underlying microbial populations. Both the bacterial and eukaryotic communities strongly resembled high-altitude and high latitude freshwater environments. In spite of high alkenone concentrations in the water column, and corresponding high haptophyte rRNA gene copy numbers, haptophyte pyrotag sequences were not the most abundant eukaryotic tag, suggesting that sequencing biases obscured relative abundance data. With over 170 haptophyte tag sequences, we observed only one haptophyte algal Operational Taxonomic Unit, a prerequisite for accurate paleoclimate reconstruction from the lake sediments. Our study is the first to examine microbial diversity in a Greenland lake using next generation sequencing and the first to target an extreme haptophyte bloom event. Our results provide a context for future explorations of aquatic ecology in the warming arctic.
\end{abstract}

Keywords: haptophytes, pyrosequencing, alkenones, lake bloom, arctic

\section{INTRODUCTION}

Oligosaline lakes (salinity $0.5-5 \mathrm{ppt}$ ) develop in polar regions near ice sheets where evaporation exceeds precipitation and provide a unique habitat apart from the more common glacially derived freshwater lakes. These high latitude lakes serve as sensitive indicators of the ecosystem response to global climate change (Quayle et al., 2002; Marchetto et al., 2004) as their low salinity reflects small changes in hydrological balance. In the past decade alone, southwestern Greenland has undergone marked warming, and major warming is predicted for the future (Bennike et al., 2010). Microbial surveys targeting the $18 \mathrm{~S}$ ribosomal RNA (rRNA) gene have revealed previously unknown diversity in microbial eukaryotes lineages such as cryptomonads, katablepharids, dinoflagellates, and Perkinsea (Slapeta et al., 2005; Logares et al., 2007; ShalchianTabrizi et al., 2011). However, haptophyte algae have been largely absent from these studies, potentially the result of naturally low haptophyte abundances in the environments selected such as deep sea habitats or anoxic lakes (Stoeck et al., 2009, 2010; Edgcomb et al., 2011; Pawlowski et al., 2011; Shalchian-Tabrizi et al., 2011). The GC-rich haptophyte genomes may also hinder amplification reactions that use universal primer sets (Moon-van der Staay et al., 2001; Liu et al., 2009; Stoeck et al., 2010). In this study, we targeted the haptophyte-rich waters of an arctic oligosaline lake spring bloom event to shed light on the microbial diversity of these unique ecosystems.

Lake BrayaSø in southwestern Greenland experiences a seasonal haptophyte bloom approximately 2 weeks after ice-off (D'Andrea et al., 2011). These haptophyte blooms result in exceptional abundances of alkenones in BrayaSø sediments $(82 \mathrm{mg} / \mathrm{g}$ total organic carbon, D'Andrea and Huang, 2005) that provide the first quantitative temperature record for the past 5000 years for southwestern Greenland (D'Andrea et al., 2011). Only a few species of haptophyte algae, in the order Isochrysidales, produce alkenone lipids. These species and their alkenone lipids have been extensively studied in marine environments, where alkenones are preserved in marine sediments as a record of sea surface temperature back through time (Volkman et al., 1980; Marlowe et al., 1984; Brassell et al., 1986; Prahl and Wakeham, 1987; Müller et al., 1998; Conte et al., 2006). The endeavor to extend this alkenone-based proxy to the continents has resulted in pan-continental surveys of lake 
sediments and waters for alkenone-producing haptophyte algae. The use of haptophyte-specific primers targeting environmental DNA has revealed considerable diversity in lake-dwelling haptophytes (Coolen et al., 2004; D'Andrea et al., 2006; Theroux et al., 2010). However, these haptophytes are largely absent in molecular surveys targeting universal genes and microbial diversity studies of haptophyte blooms are non-existent.

Nutrient loading and seasonal irradiance levels are known to trigger marine and estuarine haptophyte blooms (Tyrrell and Merico, 2004) that occur across latitudes in both cold and coastal regions (Brown and Yoder, 1994). Increasing global temperatures will result in longer ice-free periods in arctic lakes and an increase in runoff from thawing tundra catchments, undoubtedly affecting the annual haptophyte bloom events. Given the significance of haptophyte algae in aquatic ecosystems, their absence in previous datasets, and the desire to anticipate their future response to global climate change, the objectives of our study were twofold: (1) to sequence a haptophyte-rich environment with a universal molecular approach; and (2) to produce a benchmark species survey for an arctic oligosaline lake during the spring bloom. Using high-throughput pyrotag sequencing, we targeted both bacterial and eukaryotic communities from two separate years to evaluate the consistency of the bloom-associated microbial populations. Our study provides an important baseline to contrast future BrayaSø microbial community change during its ice-free period in anticipation of a warmer Arctic possessing longer ice-free periods.

\section{MATERIALS AND METHODS SITE DESCRIPTION}

The Kangerlussuaq region of Southwestern Greenland lies at the head of the Søndre Strømfjord, $150 \mathrm{~km}$ from the ocean outlet, and has a series of saline lakes that provide ideal locations of paleoclimate reconstruction due to their anoxic hypolimnions and excellent preservation of lake sediments (Figure 1). Lake BrayaSø $\left(66.99^{\circ} \mathrm{N},-51.01^{\circ} \mathrm{W}\right)$ is a meromictic, oligosaline lake (salinity 23) that has an ice cap from September to late May. The surface area of Lake BrayaSø is approximately 72 hectares, with a maximum depth of $24 \mathrm{~m}$. The dominant salts are $\mathrm{NaCO}_{3}, \mathrm{NaHCO}_{3}$, and $\mathrm{MgHCO}_{3}$, which are delivered to the lakes via aeolian transport from nearby sand sheets and input from erosion within the lake catchments (Anderson and Brodersen, 2001). The bedrock in the region is granodioritic gneiss with occasional ultrabasic intrusions (Heggen et al., 2010). The climate is low-Arctic continental with $>500 \mathrm{~mm}$ /year of precipitation and a mean annual temperature at Kangerlussuaq of $-6^{\circ} \mathrm{C}$ (Heggen et al., 2010). The lake is calciumdepleted relative to fresh lakes of the region due to $\mathrm{CaCO}_{3}$ precipitation, and the dominant cations are $\mathrm{Na}^{+}>\mathrm{Mg}^{2+}>\mathrm{K}^{+}>\mathrm{Ca}^{2+}$ (D'Andrea, 2008). Total nitrogen is approximately $803 \mu \mathrm{g} / \mathrm{L}$ and total phosphorus is approximately $9 \mu \mathrm{g} / \mathrm{L}$ (Brutemark et al., 2006). Dissolved organic carbon is approximately $90 \mathrm{mg} / \mathrm{L}$ (Anderson et al., 2009). Alkenone lipids are present in the sediments of Lake BrayaSø (D'Andrea and Huang, 2005) and sediment trap data indicated the annual haptophyte bloom in the lake occurs approximately 2 weeks after ice-off (D'Andrea, 2008).

\section{WATER COLUMN}

We selected samples for pyrosequencing based upon chlorophyll and alkenone concentrations in the water column, choosing the 10-m depth for 2007 and 4-m depth from 2009 (Figure 2). For $2007,10-\mathrm{m}$ corresponded to the peak in chlorophyll and alkenone concentrations. For 2009, 4-m depth was slightly above the chlorophyll maximum and coincided with the alkenone concentration peak (Figure 1). The June average temperature for each sampling day in 2007 and 2009 was 11.2 and $9.9^{\circ} \mathrm{C}$, respectively (Figure 3A). The average daily air temperature for June 2007 was $10.7^{\circ} \mathrm{C}$ and for June 2009 was $10^{\circ} \mathrm{C}$ (Figure 3B).

\section{WATER SAMPLING}

The bloom event occurred in BrayaSø, Greenland in June of 2007 and 2009. For both years, we analyzed a sample collected during the first week of the haptophyte bloom. We collected geochemical data using a YSI Sonde (OH, USA) equipped with probes to measure temperature, conductivity, dissolved oxygen, and chlorophyll a fluorescence. At 1-m intervals, we collected water with a Van Dorn water sampler and preserved these samples for alkenone and genomic DNA analysis. For alkenone analysis, we filtered $1 \mathrm{~L}$ of water onto a pre-combusted $\left(550^{\circ} \mathrm{C}\right) \mathrm{GF} / \mathrm{F} 0.7 \mu \mathrm{m}, 47 \mathrm{~mm}$ glass filter, and kept it frozen until analysis. For DNA analysis, we filtered a separate liter of lake water onto a $0.2 \mu \mathrm{m}$ Sterivex ${ }^{\mathrm{TM}}$ filter

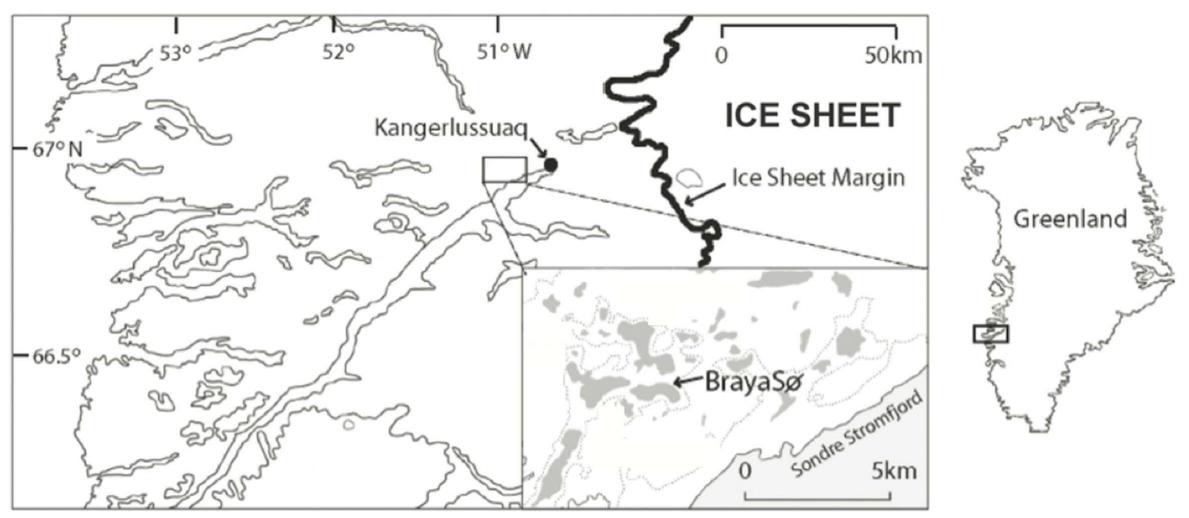

FIGURE 1 | Site map showing Lake BrayaSø in the Kangerlussuaq region, Greenland. Modified from D'Andrea et al. (2006). 


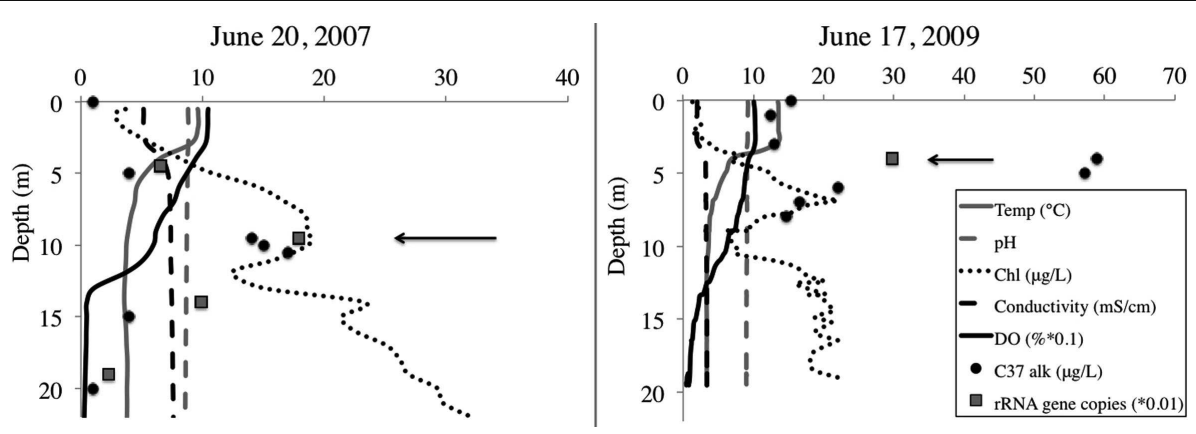

FIGURE 2 | BrayaSø water column. Left panel shows 2007 sampling profile, and right panel shows 2009 sampling profile. Arrows denote sample depth for the samples we sequenced Dissolved oxygen (DO) is decreased one order of magnitude and haptophyte rRNA gene copy number is decreased two orders of magnitude to plot along the same axis.
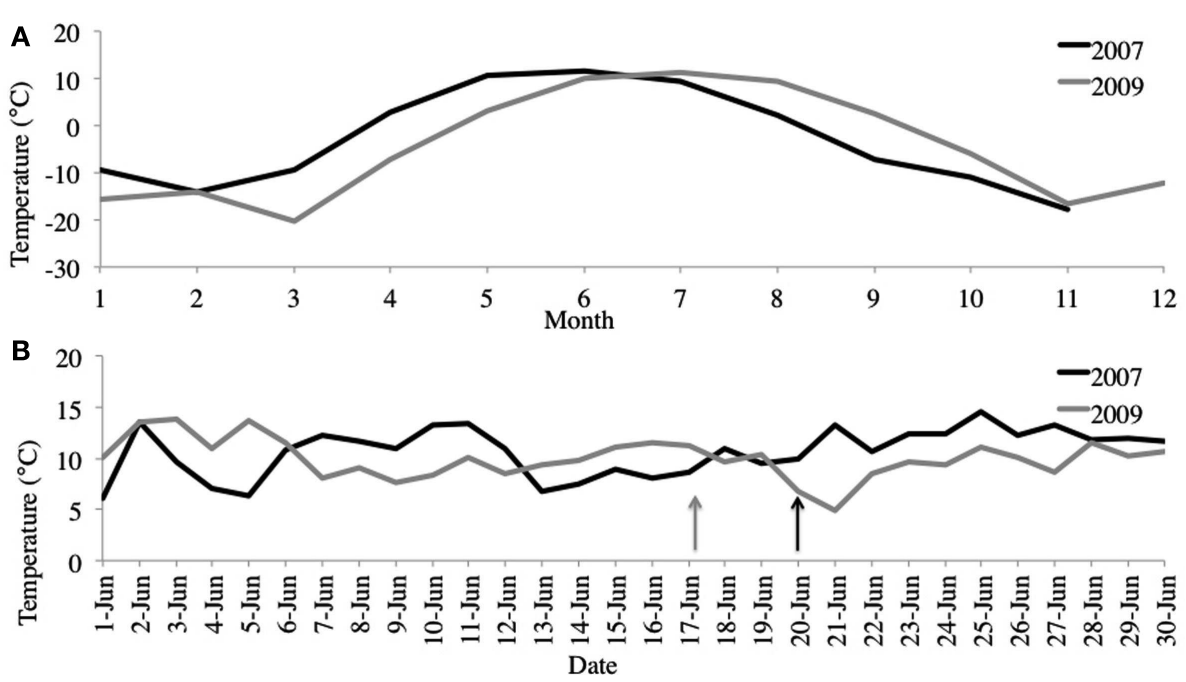

FIGURE 3 | (A) June average air temperatures for 2007 and 2009. (B) Average monthly air temperatures for 2007 and 2009. Station data from Kangerlussuaq, Greenland (67.017 N, -50.700W). http://www.ncdc.noaa.gov/oa/ncdc.html. Arrows denote sampling dates.

(Millipore, Billerica, MA, USA), flooded the filter with Puregene lysis buffer (Qiagen, Valencia, CA, USA), and froze it at $-20^{\circ} \mathrm{C}$ until processing. We selected samples for sequencing based on maximum alkenone concentrations.

\section{LIPID ANALYSIS}

Alkenone extraction was after D'Andrea and Huang (2005). Alkenone samples and DNA samples were sourced from the same water sample. We freeze-dried and homogenized samples manually. We extracted samples with nine, 1 Dichloromethane (DCM), Methanol $(\mathrm{MeOH})$ using an Accelerated Solvent Extractor ASE200 (Dionex, Sunnyvale, CA, USA). Extracts were separated into acid and neutral fractions using a solution of DCM, Isopropyl alcohol 2:1 (v/v). The neutral fraction was further separated into aliphatic (hexane elution), ketone (DCM), and alcohol (ethyl acetate:hexane 1:3) fractions using a flash silica gel column. The DCM fraction was analyzed using an Agilent 6890plus Gas Chromatograph Flame Ionization Detector (GC-FID) (Santa Clara, CA, USA) for quantification. Chromatograms were compared to previously reported alkenone standards and their GC retention times (de Leeuw et al.,
1980; Marlowe et al., 1984). Alkenone concentrations were determined from GC-FID analysis of the ketone fractions based on an internal $\mathrm{C}_{36}$ alkane standard.

\section{DNA EXTRACTION}

We extracted Sterivex ${ }^{\mathrm{TM}}$ filters using a Qiagen Puregene Cell Kit (Venlo, Netherlands) according to the manufacturer's instructions. Genomic DNA was polyethylene glycol (PEG) purified (LaMontagne et al., 2002) to remove proteins and other contaminants that inhibit PCR reactions. DNA was suspended in PEG at $4^{\circ} \mathrm{C}$ overnight, centrifuged, and the pellet rinsed with ethanol. The DNA was resuspended in DNA hydration solution (Qiagen). We quantified total extracted genomic DNA yields using a NanoDrop nucleic acid spectrophotometer (Thermo Scientific, Wilmington, DE, USA) to ensure they were RNA-free.

\section{QUANTITATIVE POLYMERASE CHAIN REACTION}

Purified DNA extracts were also subjected to real-time quantitative polymerase chain reaction (qPCR) to gauge haptophyte cell concentrations with depth and ensure that the sample selected for 
sequencing was at the point of highest haptophyte cell concentration in the water column. We performed the qPCR reaction using $18 \mathrm{~S}$ rRNA gene haptophyte-specific primers Prym-429F (5'-GCG CGT AAA TTG CCC GAA- $\left.3^{\prime} ; T_{\mathrm{m}}=65^{\circ} \mathrm{C}\right)$, and Prym-887R $\left(5^{\prime}-\right.$ GGA ATA CGA GTG CCC CTG AC- $3^{\prime} ; T_{\mathrm{m}}=62^{\circ} \mathrm{C}$ ) (Simon et al., 2000; Coolen et al., 2004). These primers yield an amplicon that is approximately $463 \mathrm{bp}$ in size. These primers have previously been screened for specificity: the forward primer Prym-429F is $100 \%$ specific for Haptophyta order Prymnesiales and matched 93\% of orders Coccosphaerales, Isochrysidales, Prymnesiales, the genus Pleurochrysis, as well as unclassified haptophytes (Coolen et al., 2004). The reverse primer is specific to Prymnesiophyceae (Simon et al., 2000). We further confirmed primer specificity using the ARB probematch tool in SILVA ARB database v111 (Pruesse et al., 2007). This SSU reference database contains 739,633 high quality 16S/18S rRNA gene sequences. The Prym429F primer matched $72 \%$ of full-length $18 \mathrm{~S}$ rRNA gene haptophyte sequences with two mismatches, and no non-haptophyte sequences. The Prym88R primer returned $99.3 \%$ of haptophyte sequences with one mismatch and no non-haptophyte sequences.

The qPCR reactions were run in triplicate, including a notemplate control, on an Applied Biosystems StepOnePlus ${ }^{\mathrm{TM}}$ RealTime PCR System (Foster City, CA, USA), using a SYBR Green I assay. We also ran a positive control of Isochrysis galbana DNA extracted from a culture with cell concentrations at $1.5 \times 10^{6}$ cells $/ \mathrm{ml}$. The $C_{\mathrm{q}}$ for each sample had a deviation of less than 0.5 . Each $20 \mu$ l reaction contained $7.2 \mu$ l of sterile water, $10 \mu \mathrm{l}$ of KAPA SYBR ${ }^{\circledR}$ FAST Universal $2 \times$ qPCR Master Mix (Woburn, MA, USA), $0.4 \mu \mathrm{l}$ each of the forward and reverse primers $(0.2 \mu \mathrm{M})$ and $2 \mu \mathrm{l}$ of template DNA. Template DNA ranged in concentration from 2 to $10 \mathrm{ng} / \mu \mathrm{l}$. The qPCR cycling program was after Coolen et al. (2009) and consisted of 38 cycles of denaturation at $94^{\circ} \mathrm{C}$ for $30 \mathrm{~s}$, annealing at $62^{\circ} \mathrm{C}$ for $40 \mathrm{~s}$, primer extension at $72^{\circ} \mathrm{C}$ for $60 \mathrm{~s}$, a photo step of $80^{\circ} \mathrm{C}$ for $20 \mathrm{~s}$. We used between $10^{1}$ and $10^{6}$ copies (10-fold dilution series) of linearized plasmids containing the 18S rRNA gene of Isochrysis galbana CCMP1323 as the external standard to calibrate the copy numbers of haptophyte RNA genes in the BrayaSø water samples. Our standard curve was established using four points of the diluted standard, with an $\mathrm{R}^{2}$ value of $>0.999$ and slope of -3.991 . Our reaction efficiency was $78.1 \%$. We used StepOne Software version 2.2 (Applied Biosystems) to analyze our results. These conditions are reported in accordance with the Minimum Information for Publication of Quantitative Real-Time PCR Experiments (MIQE) guidelines (Bustin et al., 2009).

\section{PYROSEOUENCING}

We performed genomic DNA amplifications using eukaryotic and bacterial-specific primers targeting the V9 (Amaral-Zettler et al., 2009) or V6-V4 (Morrison and Sogin, in preparation) regions, respectively. Eukaryotic sequences were generated using a Genome Sequencer FLX (Roche, Switzerland) with the GS-LR70 long-read sequencer kit at the Marine Biological Laboratory Keck Sequencing Facility. Amplifications and sequencing for eukaryotic sequences were after Amaral-Zettler et al. (2009). We sequenced the V6-V4 hypervariable region of the bacterial 16S rRNA gene using bacterial primers $515 \mathrm{~F}$ and $1046 \mathrm{R}$ on a Roche GS FLX pyrosequencer using GS FLX Titanium Series reagents (Roche Diagnostics, Basel, Switzerland) following manufacturer's protocols. Sequences were trimmed and screened for quality after Huse et al. (2007). To assign taxonomy to the remaining qualitycontrolled tags, we used the Global Alignment for Sequence Taxonomy (GAST) algorithm (Huse et al., 2008). Tag sequences were grouped into Operational Taxonomic Units using SLP-PWAL (refer to Huse et al., 2010), with bacterial sequences clustered at $3 \%$ and eukaryotic sequences clustered at $6 \%$. Venn diagrams were constructed using BioVenn (Hulsen et al., 2008). Bacterial diversity estimates were calculated using EstimateS v8.2.0 (Colwell, 2005) and CatchAll (Bunge, 2011). The open source Investigation/Study/Assay (ISA) (Sansone et a., 2012) metadata-tracking framework was used to curate the datasets and format them for submission to the NCBI SRA database. All sequences have been deposited in the NCBI Sequence Read Archive (SRA) under the SRA number SRA059384, and are MIMARKS compliant (Yilmaz et al., 2011).

\section{RESULTS AND DISCUSSION WATER COLUMN}

Both 2007 and 2009 samples were selected from the first week of the 2-week haptophyte bloom. In both years, secchi depth was $5 \mathrm{~m}$ indicating the photic zone terminated at approximately 10 $12.5 \mathrm{~m}$ depth. The alkenone peak in 2007 corresponded to the oxycline at $10 \mathrm{~m}$ depth, whereas the alkenone peak in 2009 was at the thermocline.

Quantitative PCR analysis confirmed that the water sample from peak alkenone depth corresponded to peak haptophyte cell numbers (Table 1, Figure 2). The structure of the water column between the 2 years was markedly different, with chlorophyll peaking at $10 \mathrm{~m}$ depth in 2007 and about $6.5 \mathrm{~m}$ depth in 2009. Alkenone concentrations peaked at $15 \mu \mathrm{g} / \mathrm{L}$ in 2007 and about $59 \mu \mathrm{g} / \mathrm{L}$ in 2009. Correspondingly, rRNA gene copies peaked at 2146 copies/mL in 2007 and 9898 copies/mL in 2009 (Figure 1). This equates to approximate cellular alkenone concentrations of $6-7 \mathrm{ng} /$ cell if the $18 \mathrm{~S}$ rRNA gene copies occur singularly or $3-3.5 \mathrm{ng} /$ cell if there are two copies of the $18 \mathrm{~S}$ rRNA gene in these haptophytes. This is on par with previously observed cellular alkenone concentrations in lacustrine haptophytes of 0.009 2 pg/cell (Marlowe et al., 1984; Versteegh et al., 2001). Given

Table 1 | BrayaSø water column $\mathrm{C}_{37}$ alkenone concentration and haptophyte rRNA gene copy number.

\begin{tabular}{lccl}
\hline Date & Water depth $(\mathbf{m})$ & {$\left[\mathbf{C}_{\mathbf{3 7}}\right](\boldsymbol{\mu g} / \mathbf{L})$} & $\begin{array}{l}\text { Haptophyte rRNA } \\
\text { gene copies/mL }\end{array}$ \\
\hline $6 / 20 / 07$ & 5 & 4 & 649 \\
$6 / 20 / 07$ & $10^{*}$ & 15 & 1,788 \\
$6 / 20 / 07$ & 14 & 4 & 986 \\
$6 / 20 / 07$ & 20 & 1 & 230 \\
$6 / 17 / 09$ & $4^{*}$ & 59 & 2,969 \\
Isochrysis galbana & & & 1,493 \\
control & & &
\end{tabular}

Asterisks $\left(^{*}\right)$ denote samples chosen for pyrosequencing. 
that Lake BrayaSø has the highest sedimentary concentrations of alkenones ever reported (D'Andrea and Huang, 2005), the high cellular concentrations as estimated by our qPCR analysis is not surprising. Our results also agree with observations by Boere et al. (2011) that alkenone concentrations can serve as a proxy for haptophyte cell numbers.

\section{BACTERIAL COMMUNITY DIVERSITY}

A total of 6,409 bacterial OTUs were observed between 2007 and 2009 (Figure 4A). The 2 years had comparable OTU yields, 2883 from 2007 and 2727 from 2009, yet shared only 13\% of their OTUs. This overlap in OTUs was surprisingly low, considering reports from other arctic lake surveys demonstrating up to $73 \%$ overlap in bacterial community membership (Crump et al., 2003). When singletons were ignored, this overlap increased to $44 \%$ (Figure $4 B$ ), indicating a third of the taxon differences came from the rarest members of the community. Our study revealed much greater bacterial diversity at the phylum level, 25 phyla, than previous studies from freshwater and oligosaline lakes on the Tibetan plateau that identified only 13 phyla (Liu et al., 2010). The estimates of alpha diversity of the bacterial community generated species richness estimates with overlapping confidence bounds (Table 2), demonstrating that our similar OTU yields reflected the similar alpha diversity or richness during the 2 years.
The Morisita-Horn index of similarity, an abundance-based distance measure of beta diversity, was 0.848 (complete overlap $=1$; Table 2) indicating the most abundant species were present in both 2007 and 2009. Of the most abundant bacterial OTUs (Table 3A), the notable difference between communities in 2007 and 2009 was the presence of the sulfur-oxidizing bacteria in 2009 (Thiomicrospira, Sulfurovum, Sulfuricurvum) and fewer Flavobacteria in 2009. This flavobacterial OTU matched environmental sequences from freshwater environments, including $100 \%$ sequence identity to a bacterium isolated during a spring phytoplankton bloom in Lake Zurich (Eckert et al., 2011) and bacteria from lakes on the Tibetan plateau (Zhang and Liu, unpublished, GenBank HM128691).

While Lake BrayaSø is oligosaline, its bacterial community resembled previously reported freshwater environments in addition to high-altitude environments. The bacterial OTUs were dominated by Actinobacteria, which are known to occur ubiquitously in terrestrial and aquatic ecosystems (Embley and Stackebrandt, 1994) and can dominate lake epilimnia (Newton et al., 2011). The most abundant actinobacterial OTU matched environmental sequences from Lake Taihu (China) and other freshwater lakes with $100 \%$ identity. The second most abundant phylum represented, the betaproteobacteria, occurs more commonly in freshwater environments than marine (Nold and Zwart, 1998) and
A

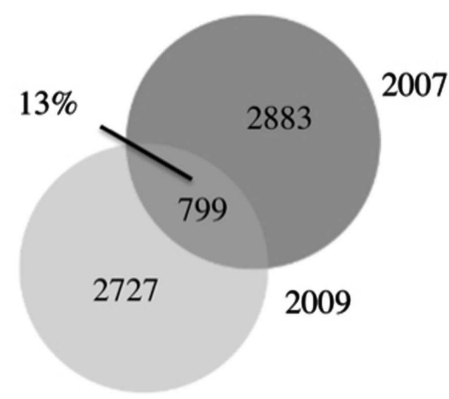

2007 tag number $=16533$

2009 tag number $=17034$
B

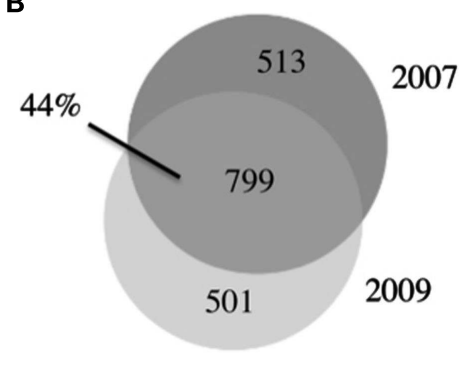

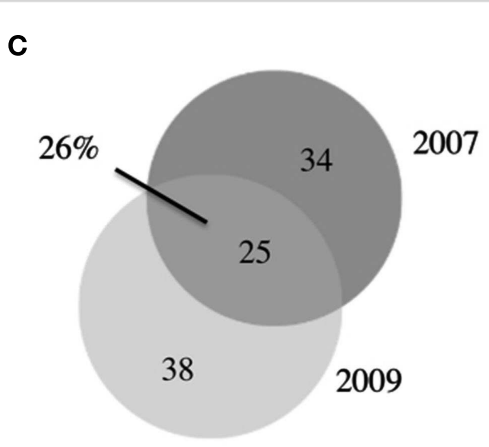

D

2007 tag number $=3794$

2009 tag number $=4081$

FIGURE 4 | Venn diagrams of microbial communities. (A) Overlap between 2007 and 2009 bacterial communities, OTUs defined at $97 \%$ similarity (B) As in (A) with singletons removed (C) overlap between 2007 and 2009 eukaryotic communities, OTUs defined at $94 \%$ similarity, (D) as in (C) with singletons removed. 
Table 2 | Sequencing summary, OTU distributions, and diversity estimates.

\begin{tabular}{|c|c|c|c|c|}
\hline & \multicolumn{2}{|c|}{ Bacteria } & \multicolumn{2}{|c|}{ Eukaryota } \\
\hline & 2007 & 2009 & 2007 & 2009 \\
\hline Sequenced tags & 16533 & 17034 & 1554 & 2795 \\
\hline Total observed OTUs & 3682 & 3526 & 59 & 63 \\
\hline Singletons & 2679 & 2604 & 18 & 25 \\
\hline Shared OTUs & 799 & & 25 & \\
\hline Shared OTUs > 1 & $72 \%$ & & $100 \%$ & \\
\hline Jaccard & 0.125 & & 0.258 & \\
\hline Sorensen & 0.222 & & 0.41 & \\
\hline Morisita-Horn & 0.848 & & & \\
\hline Bray-Curtis & 0.527 & & & \\
\hline \multicolumn{5}{|c|}{ RICHNESS ESTIMATES } \\
\hline CatchAll estimate & $\begin{array}{l}27353 \\
(-8148 \\
+12425)\end{array}$ & $\begin{array}{l}18727 \\
(-1864 \\
+2124)\end{array}$ & & \\
\hline Chao & $\begin{array}{l}11142 \\
(-838 \\
+945)\end{array}$ & $\begin{array}{l}11060 \\
(-866 \\
+979)\end{array}$ & & \\
\hline $\mathrm{ACE}$ & $\begin{array}{l}20823 \\
(-2398 \\
+2689)\end{array}$ & $\begin{array}{l}22639 \\
(-2749 \\
+3211)\end{array}$ & & \\
\hline
\end{tabular}

Upper and lower confidence bounds are 95\%. CatchAll: Estimate, estimated total species richness; Chao1, Chao1 estimated total species richness; ACE, "abundance-based coverage estimator" estimated total species richness.

represents the most abundant bacteria in glacial meltwater communities (Cheng and Foght, 2007). Overall, the most abundant bacterial taxa (Table 3A) matched sequences from other freshwater environments, and resembled that of high-altitude lakes from the Tibetan plateau in the abundance of Actinobacteria, alpha- and beta-Proteobacteria (Xing et al., 2009; Liu et al., 2010). Lakes at high-altitude experience similar environmental pressures as lakes at high latitude, including oligotrophy, low temperature, and high UV radiation in the surface waters; the similarity in their bacterial communities suggests these particular phyla can withstand harsh environmental conditions across latitudes.

Toolik Lake in Alaska experiences an increase in primary and bacterioplankton production in the first month of spring as melting snow increases organic matter and nutrient transport into the lake and allows for an increase in sunlight reaching the water column (Hobbie et al., 1983; Crump et al., 2003). A similar trend is observed on the western shelf of the Antarctic peninsula, where seasonal melting dictates irradiance levels, mixed layer depth, and organic carbon availability (Montes-Hugo et al., 2010), with an increase in primary production resulting in an increase in bacterial production. Given the increasing global temperatures, we anticipate an increased supply of organic matter into Lake BrayaSø and thus an increase in bacterioplankton production. An increasing freshwater input as a result of melting arctic tundra may affect the local hydrological balance enough to freshen Lake BrayaSø and shift the microbial community further toward one of a more freshwater composition.

\section{EUKARYOTIC COMMUNITY DIVERSITY}

Previous work in Lake BrayaSø identified only 11 eukaryotic phyla (Brutemark et al., 2006); using high-throughput sequencing we were able to identify nine times more phyla, including picoplankton that were undetectable with the previous visual identification methods (Table 3B). A total of 97 eukaryotic OTUs were observed between 2007 and 2009, with an overlap between the 2 years of only 26\% (Figure 4C; Table 2). When singletons were ignored, this number increased to $41 \%$ (Figure 4D). The eukaryotic community was dominated by diatom and ciliate OTUs in spite of the presence of a haptophyte "bloom." Diatoms are known to have high copy numbers of their $18 \mathrm{~S}$ rRNA genes, which may be the cause of the high abundance of their OTUs (Zhu et al., 2005; Not et al., 2008), as are alveolates which range up to 9,000 copies/cell (Prescott, 1994). Haptophyte 18S rRNA gene copy numbers are estimated at 2-3 copies/cell (Zhu et al., 2005) and our qPCR analysis using an Isochrysis galbana standard yielded approximate $18 \mathrm{~S}$ rRNA gene copy number are estimated at 2-3 copies per cell (Zhu et al., 2005) and our qPCR analysis using an Isochrysis galbana standard yielded approximate $18 \mathrm{~S}$ rRNA gene copy number at 1 copy per cell (Table 1 ). Given the high ciliate and diatom tag sequences, these patterns in eukaryotic community structure likely reiterate a cautionary note on the interpretation of abundance data for $18 \mathrm{~S}$ rRNA gene studies, although these concerns can be minimized when comparing intra-species abundances.

The eukaryotes present in BrayaSø were typical of freshwater meso- and eutrophic environments. Diatom-related OTUs were the most abundant tags we recovered in both 2007 and 2009 (Table 3B). The most abundant diatom OTU represented $31 \%$ of all eukaryotic tag sequences, and shared $100 \%$ sequence identity with araphid diatoms from fresh and brackish water. The second most abundant OTU in 2007 was assigned a ciliate taxonomy that matched environmental sequences from floodplain soil and an ephemeral pond to 96 and $95 \%$, respectively. In contrast, the second most abundant tag in 2009 matched a metazoan, and shared $100 \%$ sequence identity with the copepod Leptodiaptomus moorei (GenBank AY339154). This metazoan was notably absent in the 2007 dataset. Other OTUs present in $>10$-fold higher abundance in 2009 versus 2007 included Chlamydomonas, an unidentified environmental ciliate, an alveolate, and a chrysophyte (Table 3B). Of the most abundant eukaryotes, an unidentified ciliate had the greatest average GAST distance of 0.1668 (Table 3B) and is likely a novel species. The similarity of protistan lineages to other freshwater environments confirms the results from other studies increasingly showing the distinction between marine and freshwater communities (Logares et al., 2007).

Haptophytes comprised only 3\% of the eukaryotic community in 2007 and $0.4 \%$ in 2009 (Table 3B). Despite high levels of recorded alkenones at the depth of sampling, we recovered only one type of haptophyte OTU in both years albeit in much greater abundance in 2007 than 2009 (Table 3B). The most abundant tag in this OTU cluster shared $100 \%$ identity with a previously sequenced 18S rRNA gene from the BrayaSø water column (GenBank HQ446272; Theroux et al., 2010). We detected identical haptophyte V9 tag reads to this BrayaSø OTU from Toolik Lake, AK, USA (Crump et al., 2012) and Plum Island, MA, USA (AmaralZettler, personal observation) but nowhere else in the VAMPS 
Table 3 | Most abundant bacterial and eukaryotic OTUs.

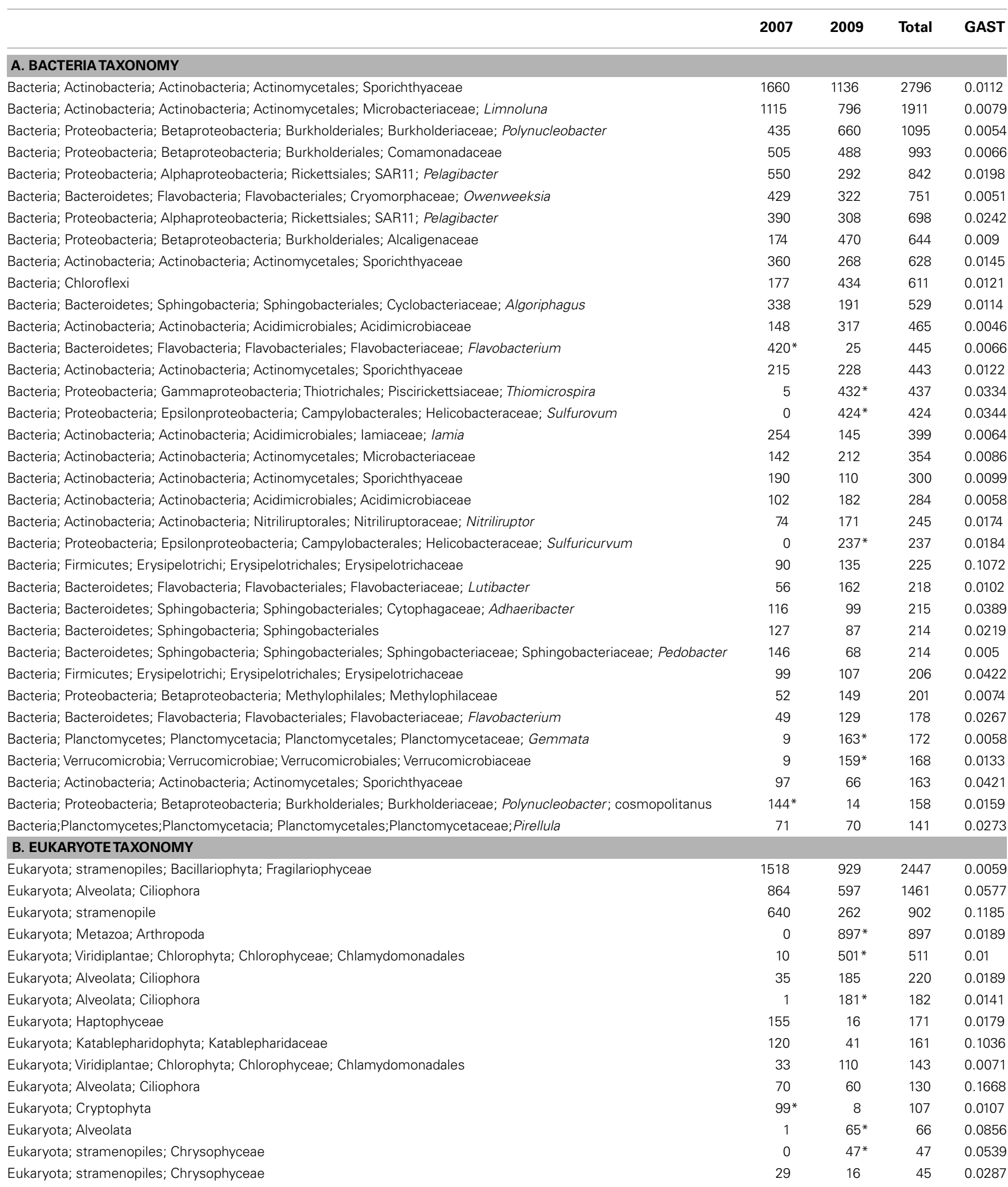

Bacterial OTUs defined at $97 \%$ similarity, eukaryote OTUs defined at $96 \%$ similarity. Asterisk (*) denotes OTUs with a relative abundance difference greater than one order of magnitude. GAST, average distance between OTU and Global Alignment for Sequence Taxonomy reference sequences. (A) The 35 most abundant bacterial tags, ranked by total relative abundance. (B) The 15 most abundant eukaryote tags, ranked by total relative abundance. 
global database (http://vamps.mbl.edu). Singularity of the haptophyte population impacts the ability to use alkenone-derived paleoclimate records from a site; the presence of multiple haptophyte species during a bloom could jeopardize the reliability of the alkenone record. The occurrence of a single haptophyte OTU in both 2007 and 2009 samples is encouraging for the use of this environment as a paleoclimate archive; alkenone-based temperature reconstructions would therefore only require a single temperature calibration for the single haptophyte species present.

The alkenone concentrations at peak alkenone depths in the water column were $15 \mu \mathrm{g} / \mathrm{L}$ in 2007 and $59 \mu \mathrm{g} / \mathrm{L}$ in 2009 . Our qPCR results (Table 1) indicated that there were approximately 1700 and 2900 haptophyte cells/mL in the 2007 and 2009 water samples, respectively. Our qPCR results also indicated that Isochrysis galbana has 1-2 copies of its 18 rRNA gene/cell. The occurrence of only 155 and 16 haptophyte tags in 2007 and 2009, respectively, suggested that the haptophyte DNA may have been dwarfed by greater copy number diatom and ciliate $18 \mathrm{~S}$ rRNA sequences. Empirical obstacles also may have resulted in the low haptophyte tag yield, including primer mismatches or difficulties amplifying GC-rich haptophyte DNA.

\section{CONCLUSION}

Arctic lakes will undoubtedly experience shifts in microbial populations with increasing annual temperatures, prolonged ice-free periods, and thawing tundra catchments. This study is the first to examine the microbial community of an artic oligosaline lake using high-throughput sequencing, providing a deeper resolution of the microbial community structure in these rapidly changing arctic environments. Using high-throughput sequencing, we were able to detect greater phylum-richness and new phyla previously unobserved in BrayaSø, the benefit of a molecular versus microscopy-based approach. Even though BrayaSø is an oligosaline lake, both the bacterial and eukaryotic communities resembled other high latitude and high-altitude freshwater environments. The low overlap in microbial communities between

\section{REFERENCES}

Amaral-Zettler, L. A., McCliment, E. A., Ducklow, H. W., and Huse, S. M. (2009). A method for studying protistan diversity using massively parallel sequencing of V9 hypervariable regions of small-subunit ribosomal RNA genes. PLOS ONE 4:e6372. doi:10.1371/journal.pone. 0006372

Anderson, N. J., and Brodersen, K. P. (2001). Determining the date of icemelt for low Arctic. Lakes along Søndre Strømfjord, southern West Greenland. Geol. Greenl. Surv. Bull. 189, 54-58.

Anderson, N. J., D'Andrea, W., and Fritz, S. C. (2009). Holocene carbon burial by lakes in SW Greenland. Glob. Chang. Biol. 15, 2590-2598.

Bennike, O., Anderson, N. J., and McGowan, S. (2010). Holocene palaeoecology of southwest Greenland inferred from macrofossils in sediments of an oligosaline lake. ISME J. 43, 787-798.

Boere, A. C., Rijpstra, W. I. C., de Lange, G. J., Malinverno, E., Sinninghe Damsté, J. S., and Coolen, M. J. L. (2011). Exploring preserved fossil dinoflagellate and haptophyte DNA signatures to infer ecological and environmental changes during deposition of sapropel S1 in the eastern Mediterranean, Paleoceanography 26, PA2204.

Brassell, S. C., Eglinton, G., Marlowe, I. T., Pflaumann, U., and Sarnthein, M. (1986). Molecular stratigraphy a new tool for climatic assessment. Nature 320, 129-133.

Brown, C., and Yoder, J. (1994). Coccolithophorid blooms in the ocean. J. Geophys. Res. 99, 7467-7482.

Brutemark, A., Rengefors, K., and Anderson, N. J. (2006). An experimental investigation of doi:10.1029/2010PA001948.

the 2007 and 2009 samplings suggested large interannual variations in microbial species. However, the 2009 sample had fewer haptophyte tags but a greater abundance of other phototrophs, suggesting the functional overlap of the eukaryotic communities may be greater than the species overlap. Future studies examining microbial populations throughout the course of a spring bloom event will help resolve these temporal shifts in species abundances and functional roles.

This study is also the first to analyze a haptophyte bloom event using next generation sequencing. We generated fewer haptophyte pyrotag sequences than expected given their alkenone biomarker concentrations in the water column. Our qPCR data confirmed that haptophyte cell numbers peaked with alkenone concentrations, and also showed that high-throughput tag sequences for haptophytes did not correspond well with qPCR counts. This result serves as a reminder that the interpretation of relative abundance data using a tag sequencing approach with eukaryotes must be done so cautiously and that complimentary, haptophyte-specific qPCR provides greater detail of cell abundances. Given the depth of DNA sequencing, and the generation of over 200 haptophyte tags, we are encouraged by the presence of a single haptophyte OTU in Lake BrayaSø, and maintain that this is a worthy location for temperature reconstruction using alkenone-based proxies. Future studies throughout the haptophyte bloom event in BrayaSø will resolve the temporal shifts in microbial communities and will help decipher the communities most susceptible to increasing arctic temperatures.

\section{ACKNOWLEDGMENTS}

This project was supported by grants from the National Science Foundation (NSF) to Yongsong Huang (ARC-0402383), a Brown University SEED grant to Yongsong Huang and Linda AmaralZettler, and an American Association of University Women American Fellowship to Susanna Theroux. We thank Melissa Paddock for her assistance with qPCR analyses and Philippe Rocca-Serra for his assistance with SRA submissions.

phytoplankton nutrient limitation in two contrasting low arctic lakes. Polar Biol. 29, 487-494.

Bunge, J. (2011). Estimating the number of species with CatchAll. Pac. Symp. Biocomput. 2011, 121-130.

Bustin, S. A., Benes, V., Garson, J. A. Hellemans, J., Huggett, J., Kubista, M., et al. (2009). The MIQE guidelines: minimum information for publication of quantitative real-rime PCR experiments. Clin. Chem. 55, 611-622.

Cheng, S. M., and Foght, J. M. (2007). Cultivation-independent and -dependent characterization of Bacteria resident beneath John Evans Glacier. FEMS Microbiol. Ecol. 59, 318-330.

Colwell, R. K. (2005). EstimateS: Statistical Estimation of Species Richness and Shared Species from Samples. Version 8.2.0. Available at: http: //purl.oclc.org/estimates.
Conte, M. H., Sicre, M.-A., Rühlemann, C., Weber, J. C., Schulte, S., Schulz-Bull, D., et al. (2006). Global temperature calibration of the alkenone unsaturation index (UK'37) in surface waters and comparison with surface sediments. Geochem. Geophys. Geosyst. 7:Q02005. doi:10.1029/2005GC001054

Coolen, M. G. L., Saenz, J. P., Giosan, L., Trowbridge, N. Y., Dimitrov, P., Dimitrov, D., et al. (2009). DNA and lipid molecular stratigraphic records of haptophyte succession in the Black Sea during the Holocene, Earth Planet. Sci. Lett. 284, 610-621.

Coolen, M. J. L., Muyzer, G., Rijpstra, W. I. C., Schouten, S., Volkman, J. K., and Damste, J. S. S. (2004). Combined DNA and lipid analyses of sediments reveal changes in Holocene haptophyte and diatom populations in an Antarctic lake. Earth Planet. Sci. Lett. 223, 225-239. 
Crump, B. C., Amaral-Zettler, L. A., and Kling, G. W. (2012). Microbial diversity in arctic freshwaters is structured by inoculation of microbes from soils. ISME J. 6, 1629-1639.

Crump, B. C., Kling, G. W., Bahr, M., and Hobbie, J. E. (2003). Bacterioplankton community shifts in an arctic lake correlate with seasonal changes in organic matter source. Appl. Environ. Microbiol. 69, 2253-2268.

D’Andrea, W. J. (2008). Development and Application of Lacustrine Alkenone Paleothermometry in Southwestern Greenland. Ph.D. dissertation, Brown University, Providence, 197.

D'Andrea, W. J., and Huang, Y. (2005). Long chain alkenones in Greenland lake sediments, Low $\delta 13 \mathrm{C}$ values and exceptional abundance. Org. Geochem. 36, 1234-1241.

D'Andrea, W. J., Huang, Y., Fritz, S. C., and Anderson, N. J. (2011). Abrupt Holocene climate change as an important factor for human migration in West Greenland. Proc. Natl. Acad. Sci. U.S.A. doi: 10.1073/pnas.1101708108

D’Andrea, W. J., Lage, M., Martiny, J. B. H., Laatsch, A. D., Amaral-Zettler, L. A., Sogin, M. L., et al. (2006). Alkenone producers inferred from well-preserved $18 \mathrm{~S}$ rDNA in Greenland lake sediments. J. Geophys. Res. 111:G03013. doi: 10.1029/2005JG000121

de Leeuw, J. W., van der Meer, F. W., Rijpstra, W. I. C., and Schenck, P. A. (1980). On the occurrence and structural identification of long chain unsaturated ketones and hydrocarbons in sediments. Phys. Chem. Earth (2002) 12, 211-217.

Eckert, E. M., Posch, M. M. S. T., Eugster, B., and Pernthaler, J. (2011). Rapid successions affect microbial $\mathrm{N}$-acetyl-glucosamine uptake patterns during a lacustrine spring phytoplankton bloom. Environ. Microbiol. 14, 794-806.

Edgcomb, V., Orsi, W., Bunge, J., Jeon, S., Christen, R., Leslin, C., et al. (2011). Protistan microbial observatory in the Cariaco Basin, Caribbean. I. Pyrosequencing vs. sanger insights into species richness. ISME J. 5, 1344-1356.

Embley, T. M., and Stackebrandt, E. (1994). The molecular phylogeny and systematics of the actinomycetes. Annu. Rev. Microbiol.48, 257-289.

Heggen, M. P., Birks, H. H., and Anderson, N. J. (2010). Long-term ecosystem dynamics of a small lake and its catchment in west Greenland. Holocene 20, 1207-1222.
Hobbie, J. E., Corliss, T. L., and Peterson, B. J. (1983). Seasonal patterns of bacterial abundance in an arctic lake. Arctic Alpine Res. 15, 253-259.

Hulsen, T., De Vlieg, J., and Alkema, W. (2008). BioVenn - a web application for the comparison and visualization of biological lists using areaproportional Venn diagrams. BMC Genomics 9:488. doi:10.1186/14712164-9-488

Huse, S. M., Huber, J. A., Morrison, H. G., Sogin, M. L., and Welch, D. M. (2007). Accuracy and quality of massively parallel DNA pyrosequencing. Genome Biol. 8, R143.

Huse, S. M., Huber, J. A., Welch, D. M., Relman, D. A., and Sogin, M. L. (2008). Exploring microbial diversity and taxonomy using SSU rRNA hypervariable tag sequencing. PLoS Genet. 4:e1000255. doi:10.1371/journal.pgen.1000255

Huse, S. M., Mark Welch, D., Morrison, H. G., and Sogin, M. L. (2010). Ironing out the wrinkles in the rare biosphere through improved OTU clustering. Environ. Microbiol. 1889-1898.

LaMontagne, M. G., Michel, F. C., Holden, P. A., and Reddy, C. A. (2002). Evaluation of extraction and purification methods for obtaining PCR-amplifiable DNA from compost for microbial community analysis. J. Microbiol. Methods 49, 255-264.

Liu, H., Probert, I., Uitz, J., Claustre, H., Aris-Brosou, S., Frada, M. (2009). Extreme diversity in noncalcifying haptophytes explains a major pigment paradox in open oceans. Proc. Natl. Acad. Sci. U.S.A. 106, 12803-12808.

Liu, X., Yao, T., Kang, S., Jiao, N., Zeng, Y., and Liu, Y. (2010). Bacterial community of the largest. Oligosaline lake, Namco on the Tibetan plateau. Geomicrobiol. J. 27, 669-682.

Logares, R., Shalchian-Tabrizi, K., Boltovskoy, A., Rengefors, K. (2007). Extensive dinoflagellate phylogenies indicate infrequent marinefreshwater transitions. Mol. Phylogenet. Evol. 45, 887-903.

Marchetto, A., Mosello, R., Rogora, M., Manca, M., Boggero, A., Morabito, G. (2004). The chemical and biological response of two remote mountain lakes in the Southern Central Alps (Italy) to twenty years of changing physical and chemical climate. $J$. Limnol. 63, 77-89.

Marlowe, I. T., Green, J. C., Neal, A. C., Brassell, S. C., Eglinton, G., and Course, P. A. (1984). Long-Chain (n-C37-C39) alkenones in the prymnesiophyceae. Distribution of alkenones and other lipids and their taxonomic significance. Eur. J. Phycol. 19, 203-216.

Montes-Hugo, M., Sweeney, C., Doney, S. C., Ducklow, H., Frouin, R., Martinson, D. G., et al. (2010). Seasonal forcing of summer dissolved inorganic carbon and chlorophyll a on the western shelf of the Antarctic Peninsula. J. Geophys. Res. 115:C03024. doi:10.1029/2009JC005267

Moon-van der Staay, S. Y., De Wachter, R., and Vaulot, D. (2001). Oceanic 18S rDNA sequences from picoplankton reveal unsuspected eukaryotic diversity. Nature 409, 607-610.

Müller, P. J., Kirst, G., Ruhland, G., von Storch, I., and Rosell-Mele, A. (1998). Calibration of the alkenone paleotemperature index Uk37' based on core-tops from the eastern South Atlantic and the global ocean $\left(60^{\circ} \mathrm{N}\right.$ $\left.60^{\circ} \mathrm{S}\right)$. Geochim. Cosmochim. Acta 62, 1757-1772.

Newton, R. J., Jones, S. E., Eiler, A., McMahon, K. D., and Bertilsson, S. (2011). A guide to the natural history of freshwater lake bacteria. Microbiol. Mol. Biol. Rev. 75, 14-49.

Nold, S. C., and Zwart, G. (1998). Patterns and governing forces in aquatic microbial communities. Aquat. Ecol. 32, 17-35.

Not, F., Latasa, M., Scharek, R., Viprey, M., Karleskind, P., Balague, V., et al. (2008). Phytoplankton diversity across the Indian Ocean: a focus on the picoplanktonic size fraction. Deep Sea Res. Part I Oceanogr. Res. Pap. 55, 1456-1473.

Pawlowski, J., Christen, R., Lecroq B., Shahbazkia, H. R., AmaralZettler, L., and Guillou, L. (2011). Eukaryotic richness in the abyss, insights from pyrotag sequencing. PLOS ONE 6:e18169. doi:10.1371/journal.pone.0018169

Prahl, F. G., and Wakeham, S. G. (1987). Calibration of unsaturation patterns in long-chain ketone compositions for paleotemperature assessment. Nature 330, 367-369.

Prescott, D. M. (1994). The DNA of ciliated protozoa. Microbiol. Rev. 58, 233-267.

Pruesse, E., Quast, C., Knittel, K., Fuchs, B., Ludwig, W., Peplies, J., et al. (2007). SILVA: a comprehensive online resource for quality checked and aligned ribosomal RNA sequence data compatible with ARB. Nucleic Acid Res. 35, 7188.

Quayle, W. C., Peck, L. S., Peat, H., Ellis-Evans, J. C., and Harrigan, P. R.
(2002). Extreme responses to climate change in Antarctic lakes. Science 295, 645.

Sansone, S.-A., Rocca-Serra, P., Field, D., Maguire, E., Taylor, C., Hofmann, O., et al. (2012). Towards interoperable bioscience data. Nat. Genet. 44, 121-126.

Shalchian-Tabrizi, K., Reier-Røberg, K., Ree, D. K., Klaveness, D., and Bråte, J. (2011). Marine freshwater colonizations of Haptophytes inferred from phylogeny of environmental 18S rDNA sequences. J. Eukaryot. Microbiol. 58, 315-318.

Simon, N., Campbell, L., Ornolfsdottir, E., Groben, R., Guillou, L., Lange, M., et al. (2000). Oligonucleotide probes for the identification of three algal groups by dot blot and fluorescent whole-cell hybridization. J. Eukaryot. Microbiol. 47, 76-84.

Slapeta, J., Moreira, D., and LopezGarcia, P. (2005). The extent of protist diversity insights from molecular ecology of freshwater eukaryotes. Proc. R. Soc. Lond. B Biol. Sci. 272, 2073-2081.

Stoeck, T., Bass, D., Nebel, M., Christen, R., Jones, M. D., Breiner, H. W., et al. (2010). Multiple marker parallel tag environmental DNA sequencing reveals a highly complex eukaryotic community in marine anoxic water. Mol. Ecol. 19, 21-31.

Stoeck, T., Behnke, A., Christen, R., Amaral-Zettler, L., and RodriguezMora, M. (2009). Massively parallel tag sequencing reveals the complexity of anaerobic marine protistan communities. BMC Biol. 7:72. doi:10.1186/1741-7007-7-72

Theroux, S. M., D’Andrea, W. J., Toney, J. L., Amaral-Zettler, L. A., and Huang, Y. (2010). Phylogenetic diversity and evolutionary relatedness of alkenone producing haptophyte algae in lakes, implications for continental paleotemperature reconstructions. Earth Planet. Sci. Lett. 300, 311-320.

Tyrrell, T., and Merico, A. (2004). "Emiliania huxleyi: bloom observations and the conditions that induce them" in Coccolithophores from Molecular Processes to Global Impact, eds H. R. Thierstein and J. R. Young (Berlin: Springer), 75-97.

Versteegh, G. J. M., Riegman, R., de Leeuw, J. W., and Jansen, J. H. F. (2001). Uk37’ values for Isochrysis galbana as a function of culture temperature, light intensity and nutrient concentrations. Org. Geochem. 32, 785-794. 
Volkman, J. K., Eglinton, G., Corner, E. D. S., and Forsberg, T. E. V. (1980). Long-chain alkenes and alkenones in the marine coccolithophorid Emiliania-huxleyi. Phytochemistry 19, 2619-2622.

Xing, P., Hahn, M. W., and Wu, Q. L. (2009). Low taxon richness of bacterioplankton in high-altitude lakes of the eastern Tibetan Plateau, with a predominance of Bacteroidetes and Synechococcus spp. Appl. Environ. Microbiol. 75, 7017-7025.
Yilmaz, P., Kottmann, R., Field, D., Knight, R., Cole, J. R., AmaralZettler, L., et al. (2011). Minimum information about a marker gene sequence (MIMARKS) and minimum information about any $(\mathrm{x})$ sequence (MIxS) specifications. Nat. Biotechnol. 29, 415-420.

Zhu, F., Massana, R., Not, F., Marie, D., and Vaulot, D. (2005). Mapping of picoeucaryotes in marine ecosystems with quantitative PCR of the $18 \mathrm{~S}$ rRNA gene. FEMS Microbiol. Ecol. 52, 79-92.
Conflict of Interest Statement: The authors declare that the research was conducted in the absence of any commercial or financial relationships that could be construed as a potential conflict of interest.

Received: 01 August 2012; accepted: 19 November 2012; published online: 17 December 2012.

Citation: Theroux S, Huang $Y$ and Amaral-Zettler L (2012) Comparative molecular microbial ecology of the spring haptophyte bloom in a Greenland arctic oligosaline lake. Front. Microbio. 3:415. doi: 10.3389/fmicb.2012.00415

This article was submitted to Frontiers in Extreme Microbiology, a specialty of Frontiers in Microbiology.

Copyright (C) 2012 Theroux, Huang and Amaral-Zettler. This is an open-access article distributed under the terms of the Creative Commons Attribution License, which permits use, distribution and reproduction in other forums, provided the original authors and source are credited and subject to any copyright notices concerning any third-party graphics etc. 